\title{
Riparian habitat modelling in the context of beavers (Castor fiber) repopulation in Braşov, Romania
}

\author{
Claudiu Paşca*, Liviu Ungureanu, Georgeta lonescu, Marius Popa \\ \& Alexandru Gridan
}

\begin{abstract}
The reintroduction of Eurasian beaver (Castor fiber) in Romania started in 1998 and was a complete success in terms of population and natural range enlargement. The habitat modelling capacity of beaver was more and more obvious once with the increase of population densities, demonstrating the high potential of this species to create new trophic niches for other species and implicitly biodiversity enrichment. The study was conducted on a floodplain area near the Bârsa River, where the habitat became a vegetation and fauna paradise, by the constant intervention of beavers that had colonized the area in 20092010. In the first stage of this study, the habitats were classified and existing stands, shrubs and herbaceous vegetation was demarcated according to their composition and age (for tree vegetation). Further, a habitat analysis has been performed grounded on the correlation of dendrochronological sampling and satellite images captured between 2005 and 2014. On the basis of the aforementioned method, the right moment for beaver installation within the studied area has been determined quite precisely. This study is a clear example that beavers succeed to use in their best interest the opportunities offered by nature. Moreover, through the changes they produce on the environment, beavers have a strong impact on the natural succession processes.
\end{abstract}

KEY WORDS: beaver repopulation, habitat modelling, beaver impact, dendrochronology.

Claudiu Paşca [claudiu_tasi@yahoo.com], National Institute for Research and Development in Forestry "Marin Drăcea", Braşov, Romania; Liviu Ungureanu [liviugeorgian808@yahoo.com], Faculty of Silviculture and Forest Engineering, Transilvania University of Braşov, Braşov, Romania; Georgeta Ionescu[titi@icaswildlife.ro], National Institute for Research and Development in Forestry "Marin Drăcea", Braşov, Romania; Marius Popa [mmp4444@gmail.com], National Institute for Research and Development in Forestry "Marin Drăcea”, Braşov, Romania; Alexandru Gridan [g_alexej@yahoo.com], National Institute for Research and Development in Forestry "Marin Drăcea", Braşov, Romania.

\section{Моделирование прибрежных местообитаний в контексте восстановления популяции бобров (Castor fiber) в районе Брашова, Румыния}

\author{
К. Паска*, Л. Унгуреану, Ж. Ионеску, М. Попа, А. Гридан
}

РЕЗЮМЕ. Реинтродукция евразийского бобра (Castor fiber) в Румынии началась в 1998 г. и увенчалась полным успехом в плане роста популяции и расширения ареала. Необходимость оценки емкости угодий становилась все более очевидной с увеличением плотности популяции, демонстрацией высоких способностей этого вида в создании новых трофических ниш для других видов и косвенного увеличения биоразнообразия. Исследование было проведено в пойме реки Барса, где среда обитания стала природным раем и местом постоянного обитания бобров, колонизировавших этот район в 2009-2010 гг. На первом этапе исследования была проведена классификация биотопов и оценены запасы древостоя, кустарников и травяной растительности по составу и возрасту (последнее - для деревьев). Далее был проведен анализ биотопов на основе корреляции дендрохронологических проб и спутниковых снимков, полученных в период 2005-2014 гг. На основе вышеупомянутого метода достаточно точно был определен момент заселения бобрами района исследования. Это исследование - яркий пример успешного использования бобрами возможностей окружающей среды. Кроме того, путем изменения биотопов, бобры оказывают значительное влияние на сукцессионные процессы.

КЛЮЧЕВЫЕ СЛОВА: репопуляция бобров, моделирование местообитаний, дендрохронология.

* Corresponding author 


\section{Introduction}

Eurasian beaver history in Romania was closely linked to the history of man (humans) and it has been characterized by a continued presence since ancient times. Evidence of this are numerous place names scattered throughout our days Romania's territory and fossils found in deposits of different ages in the old settlements of the ancient and medieval period.

Unfortunately, the first half of the XIX century represented the extinction of beavers from the Romanian fauna, mainly because of excessive hunting.

Increasing interest in biodiversity restoring in Europe was manifested by actions of restocking that took place during 1921-1933 in Sweden, Russia, Norway, and later in Poland and Lithuania. But these culminated in 1995-2003, when large-scale beaver reintroduction programs were implemented successfully in Hungary, Scotland, the Netherlands, Croatia, Czech Republic, Bulgaria, Belgium and England (Ionescu et al., 2010).

In Romania restocking took place in 1998-2003: 182 beaver individuals were released on Olt, Mureş and Ialomița rivers. Beavers have conquered vast territories through natural dispersal, the population being estimated now up to 2000 individuals, and it keeps growing.

\section{Description of the studied area and un- dertaken researches}

The last estimation of beaver population (2013 2014) led to the discovery of a special wetland situated $10 \mathrm{~km}$ near Braşov, in the meadow of the Bârsa River, one of the most important tributary of the upper Olt River

This area has a surface of 6.92 ha and it is a result of both natural and anthropogenic factors that led to the transformation of agricultural land into a floodplain habitat through erosion caused by the river water flow. The area is unique because it is not actually directly connected to the Bârsa's river bed. The whole wetland is the result of 11 existing springs conflation and the implementation of a water level management by beavers. Through a system of dams beavers have ensured their protection and access to food resources around shelters, increasing significantly the water surface. More than $85 \%$ of site surface is covered by willow and mixed (willow and alder) forest.

Four beaver families (20 individuals) are organized as a colony with 4 separate dens and share the same territory thanks to the abundance of food resources. Two of the biggest beaver lodges from Romania were observed in this area, with elliptical shape of $10 \times 9 \mathrm{~m}$ and nearly $2 \mathrm{~m}$ high.

The vegetation consists mostly of various species of willow with a significant percentage of black and white alder.

The area was split in seven plots according to the vegetation composition, age, and forest canopy cover:

1. Mature willow forest -1.47 ha.
2. Alder forest -1.47 ha.

3. Willow bushes -1.15 ha.

4. Swampy area $-1.02 \mathrm{ha}$.

5. Young willow -0.58 ha.

6. Willow regeneration -0.59 ha.

7. Herbaceous vegetation -0.64 ha.

Total surface - 6.92 ha.

The research presented in this paper is related to beaver ability to initiate changes in the mature willow forest by deforestation and flooding, the effect of raising water level on alder trees and the regeneration from seeds of willow forest in flooding conditions.

Beavers damming and the subsequent flooding may kill woody vegetation in one or two growing seasons which increases the surface area of unshaded water. Although willows and alder trees have a higher tolerance to stress caused by flooding compared to other species, after two or three growing seasons their roots starts to mold and the trees will die too. However, the pond edges create favourable conditions for moisture demanding plants, such as willow and alder (Rosell et al., 2005).

The result of research conducted by Little et al. (2012) reveals the fact that regional fluctuations in ponds created by beaver activity affect the distribution of wetland successional stages on the landscape. Bonner et al. (2009) suggests that the managers of wetlands may consider the beaver activity a method of managing wetland successional stages. In a study on Castor canadensis, Slabe (2007) explains that the beavers damming are very important in landscape heterogeneity, plants successions and species diversity.

\section{Aspects of habitat modelling in the ma- ture willow forest}

Prior to conducting the study we determined the age of the mature willow forest based on satellite images and, at the same time, by taking growth cores from 34 dominant trees of various species with diameter up to $24 \mathrm{~cm}$.

Although in some places the forest looks like a mature stand, the age of the biggest trees does not exceed 15-16 years. We must mention that local conditions favored vegetation to grow explosively, so most of the dominant trees show annual growth core of 8-12 $\mathrm{mm}$ (which means an annual average diameter growth of $20 \mathrm{~mm})$.

In the middle of the mature forest area beavers have created a 0.3 ha canopy gape by falling trees. We determined the moment of deforestation by using two methods:

1) based on the analysis of satellite imagery and aerophotography: the available images (from many sources) have been analyzed and compared to accentuate the intervening changes, with the main focus on the study area;

2) dendrochronological method: wood rings were taken from oldest regenerated shoots, and age was determined by numbering of annual growth rings. About 


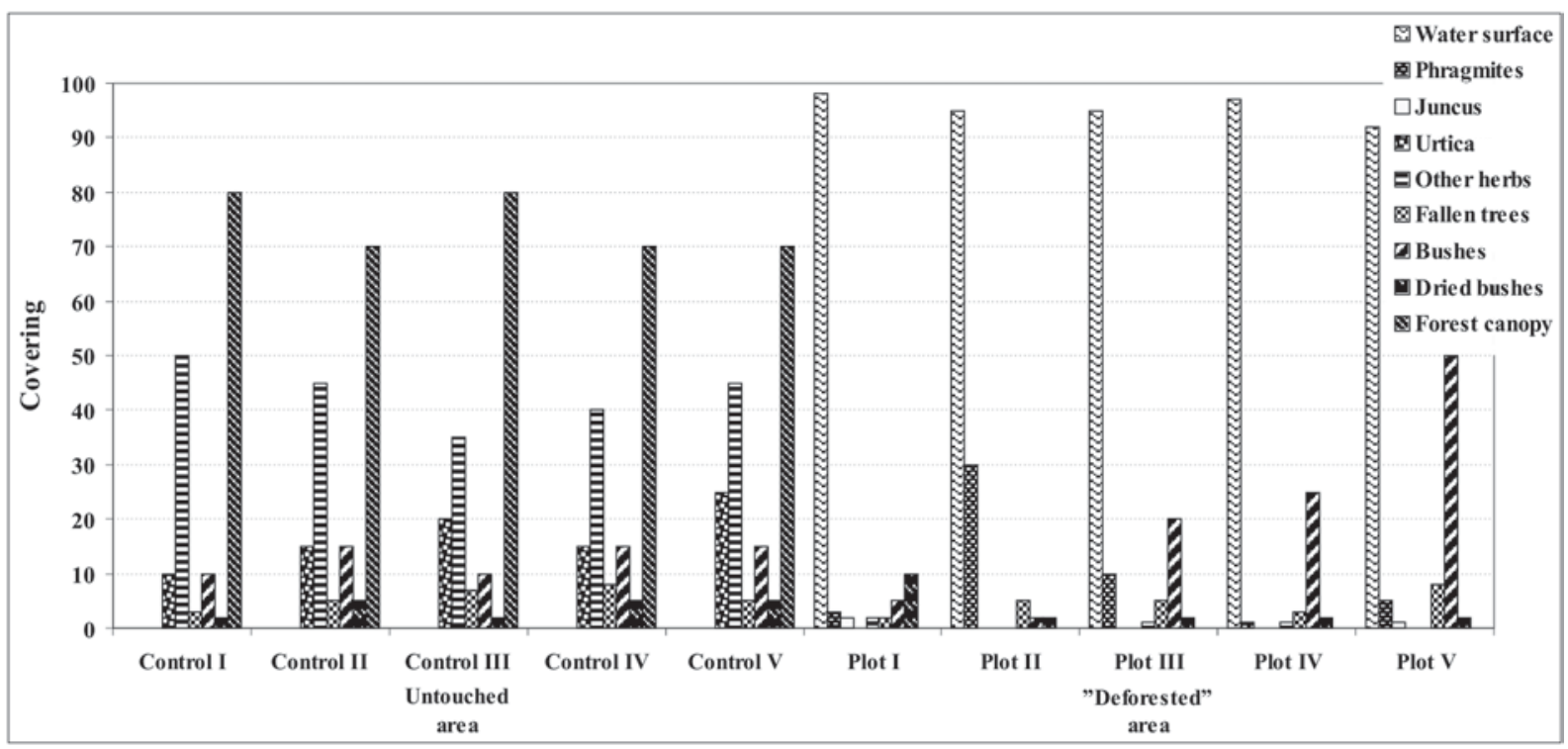

Fig. 1. Land covering categories per plots.

$7 \%$ of the trees taken down by beavers have sprouted, mainly younger trees. Because it has been observed that sprout occurred successively in several years, the oldest ones were collected from the group of shoots.

As a result, confirmed by both methods, we could conclude that the largest deforestation impact was recorded in the autumn and winter of 2011-2012.

\section{Comparative study of vegetation}

To make an assessment of the beaver modelling capacity in wetland habitats a comparative study was conducted, between a controlled surface, free of beavers influence and an "affected" one (by flooding and cuttings). In this regard, 10 samplings were: five control plots and five in "deforested" area (each plot of $25 \mathrm{~m}^{2}$ ).

In each plot an inventory of land covering was made categorised on three layers: woody overstory, woody understory and herbaceous understory in percentage (Fig. 1). In each layer of vegetation qualitative assessments were made of main categories: Phragmites, Juncus, Urtica, and other herbs for herbaceous understory, respectively fallen trees, dried bushes and green scrubs, in the woody understory (Fig. 2).

The most important changes were observed in terms of increasing water surface from 0 to $95-98 \%$. On the other hand the herbaceous understory has decreased dramatically from $50 \%$ to less than $2 \%$. Same extensive changes were observed in the forest canopy. The clearing produced by beavers has decreased canopy cover from 0.7 to 0 (complete opened land). In the flooded area, herbaceous vegetation percentage has decreased from 38.4 to $8.3 \%$. Herbaceous vegetation is poorly represented, the place of shade-loving macrophytes being taken by the hydrophilic plants. By raising the water level and taking down woody vegetation, beavers initiate the transition from forested wetland to shrub wetland, shallow marsh and aquatic bodies.

\section{Flooding effect on the growing of alder trees}

Beavers manifest an obvious selectivity for some of the species contained in the trophic offer. Given that the composition of woody vegetation in the study area is dominated by different willow species, alder trees disseminated in the stand remained unaffected by beavers.

It was observed that a part of alder trees presents a poor state of vegetation, highlighted by chlorosis and significantly reducing leaf density, although the cutting of surrounding competitor trees would have had to facilitate the growth and development of alder trees due to exposure to light. The assumption was launched that the poor condition is due to the fact that those trees are suffering because of rising water levels.

For this reason, growth cores were taken to determine the age and annual growth of 13 suffering alder trees, with the intent to correlate this phenomenon to changes in the water level caused by beavers. The data were comparable only for the period 2007-2014, although there were older trees (Fig. 3).

Analysing the results, we can say that during the first four years (2007-2010) the average growth was similar (Fig. 4). First, growth diminution (27.2\%) was registered in 2011. In the next three years, a downward trend continued till the end of 2014 (33.0\%).

In terms of value, in the first three years (20072009) average growths are almost equal, which could be explained by the fact that the area was naturally colonized by beavers not earlier than in 2008, and the impact of beavers began to manifest more strongly beginning with the year 2009 when dams and lakes that result from the embankment works became visible in satellite images. Parenthetically, it should be mentioned that our previous experience has revealed the fact that 

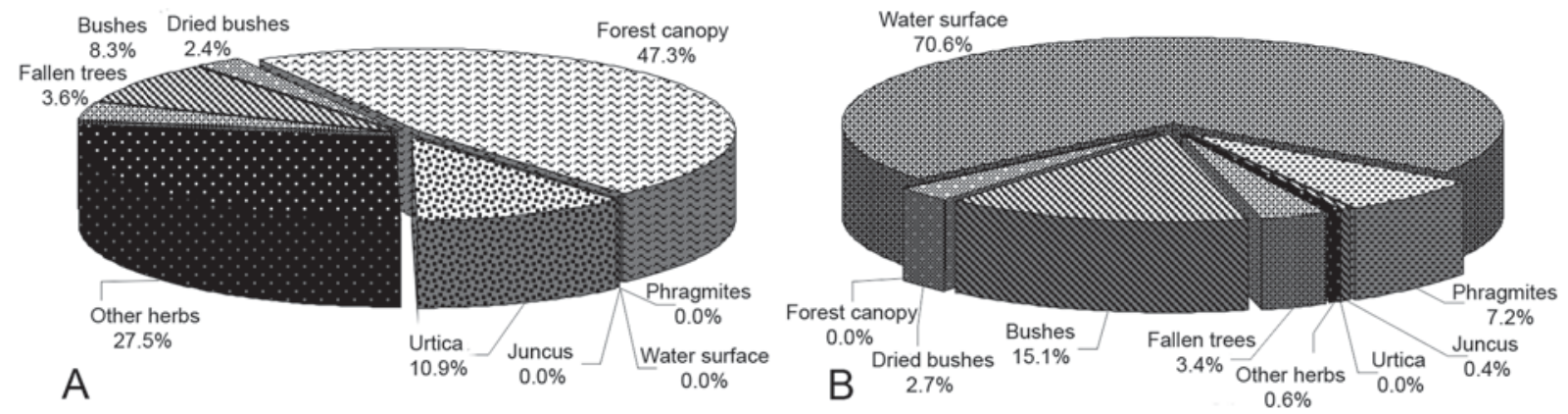

Fig. 2. The distribution of land covering categories: A — "untouched" area, B — "deforested" area.

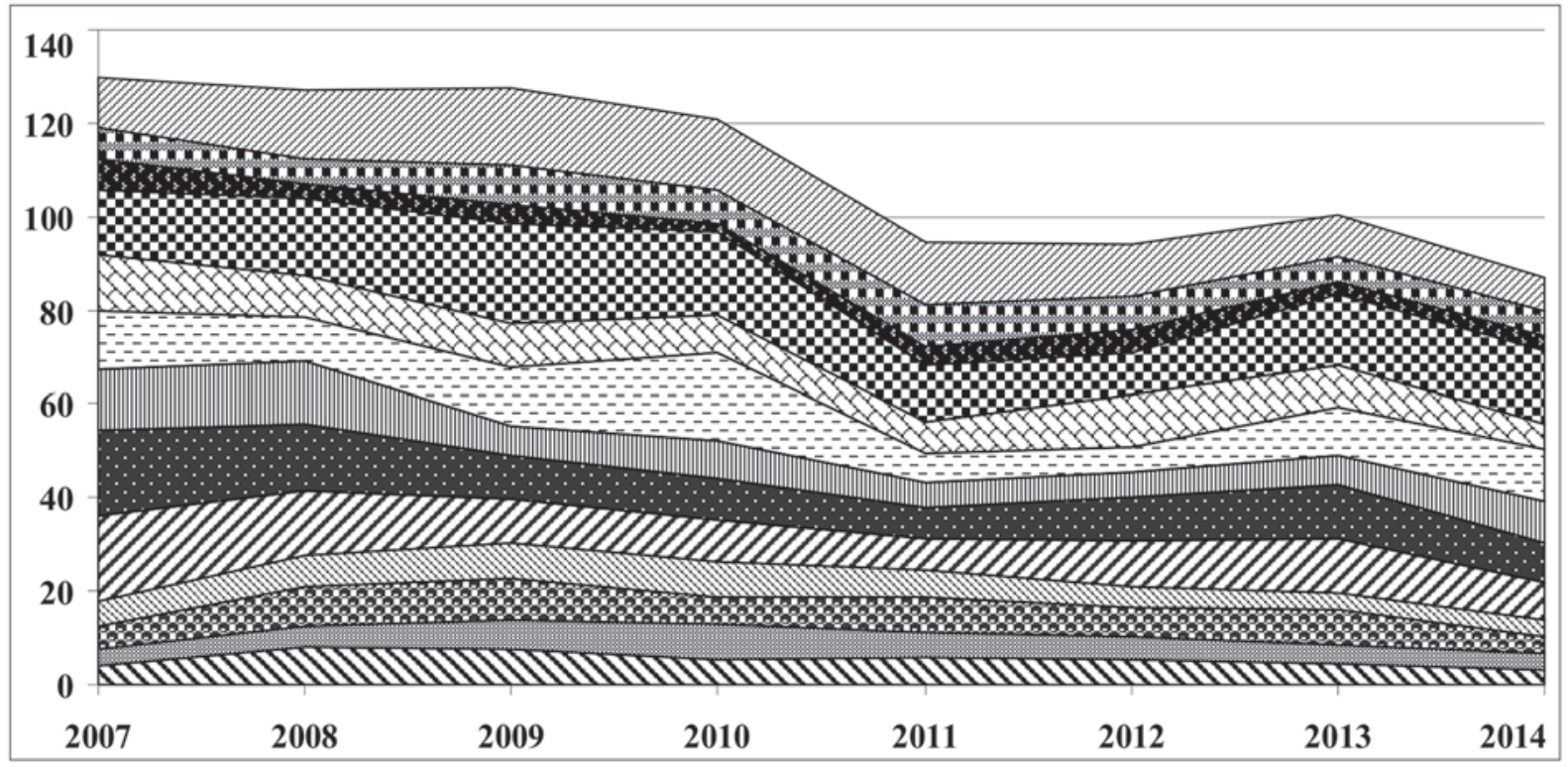

Fig. 3. Alder (Alnus sp.) cumulated annual growth (in mm).

changes in vegetation and water levels are more obvious after 1-2 years of colonization in a certain area. In addition, the impact on vegetation and biotope is directly proportional with the family size and, implicitly, trophic and spatial needs.

Alder trees which were included in the study are suffering in deep water. The annual growing rings are becoming smaller and leaves indicate a health condition becoming worse. The study will continue in the future to see whether the trees will dry out completely. It is possible that in some cases the negative influence of hydrological factors overlaps with the effect of others (e.g. biological infestation by various pests) and may act synergistically on tree drying out.

\section{The study of the young willow arboretum}

An area of 0.59 ha has been identified where seedlings consist mainly of willow species that are growing alongside herbaceous vegetation. A study was initiated that aimed to highlight the existence of relationships between and seedling development and the water level management generated by beavers through raising of water level.

In order to draw reliable conclusions about the installing of woody vegetation historical satellite images were analyzed which showed that in 2010 during the construction of the protection dam (anthropic construction) the entire area was affected by using the fertile substrate to cover the protection dam. From this point of view, 2011 can be considered the first year of revegetation. A transect has been set that respects the altitudinal gradient (and hence the water level) and a slight tilt of the land has been observed on the north-south. Analysis of historical satellite images showed a differentiated development of vegetation in the study area.

In the first phase it has been verified that the choosing the transect was fair based on the existent relation between the transect starting point and the water depth variation. Next, 37 sample plots of $1 \mathrm{~m}^{2}$ were placed on the $74 \mathrm{~m}$ long transect so that to respect the decreasing water level gradient. In each plot an inventory has been made of all woody vegetation species, and data has 


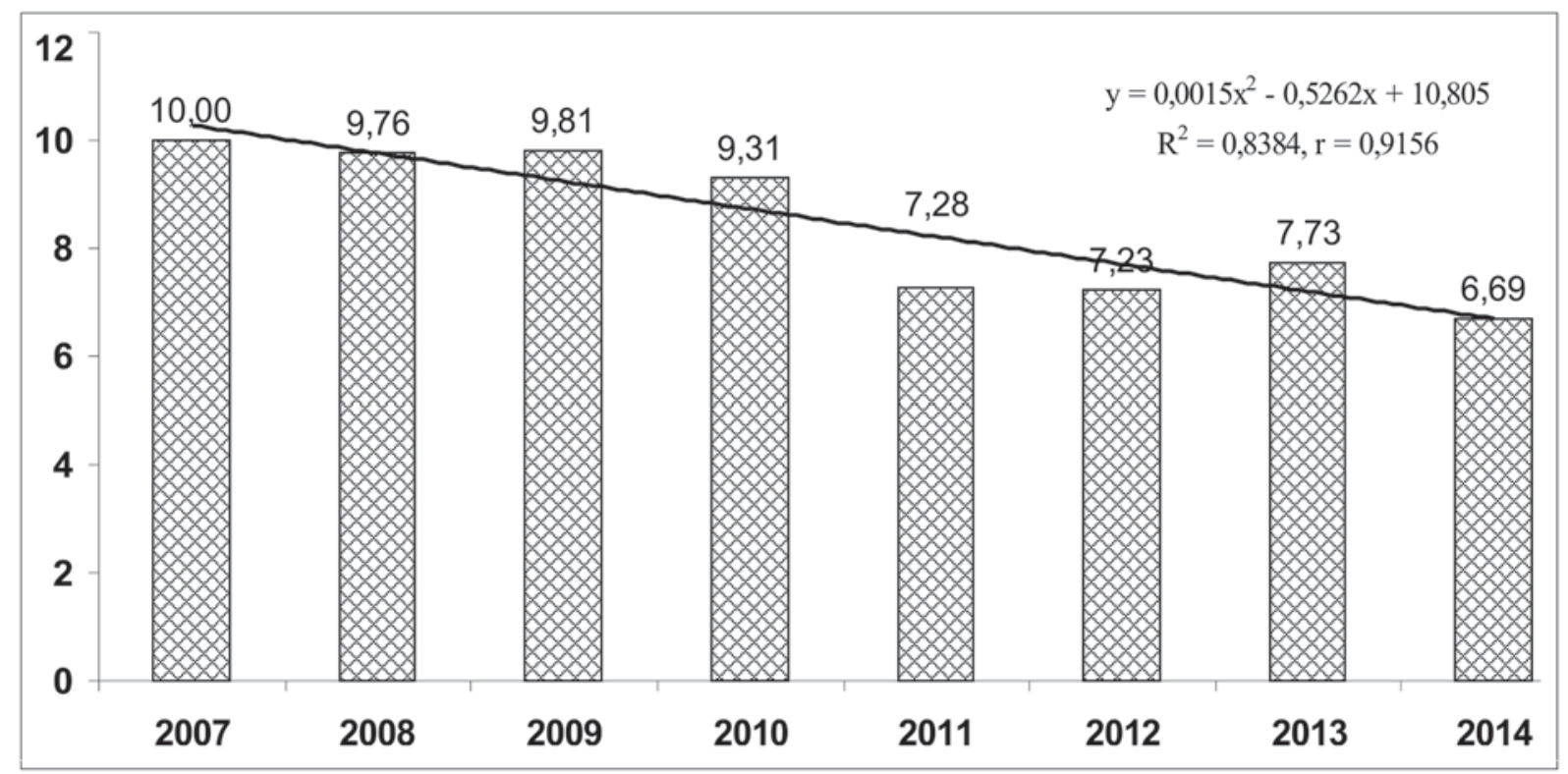

Fig. 4. Average annual growth (in mm) during 2007-2014.

been selected about tree diameter, age, canopy covering percentage and average water depth.

In each plot we did an inventory of all woody vegetation on species, and we took data on tree diameter, age, canopy covering $\%$ and average water depth. To determine the diameter and the age, entire woody vegetation was collected from every samples area and the stems have been cut with scissors at a height of $5 \mathrm{~cm}$ from the ground. A total number of 1137 specimens of trees were taken. For each an average diameter has been determined resulting from the measuring of two perpendicular diameters. The age was found by counting annual rings using a magnifying glass with $10 \mathrm{x}$ zoom factor. The data were then processed in Excel.

For the first section of $32 \mathrm{~m}$ (plot 1-18) the average age is 2.8 years, while the second $40 \mathrm{~m}$ (plot 19-37) the age is 1.2 years (Figs. 5-6). Given the fact that after the year 2012 there was no human activity which could have influenced the installation of woody vegetation, the hypothesis that raising of water level due to beavers intervention can determine installing of woody vegetation can be sustained.

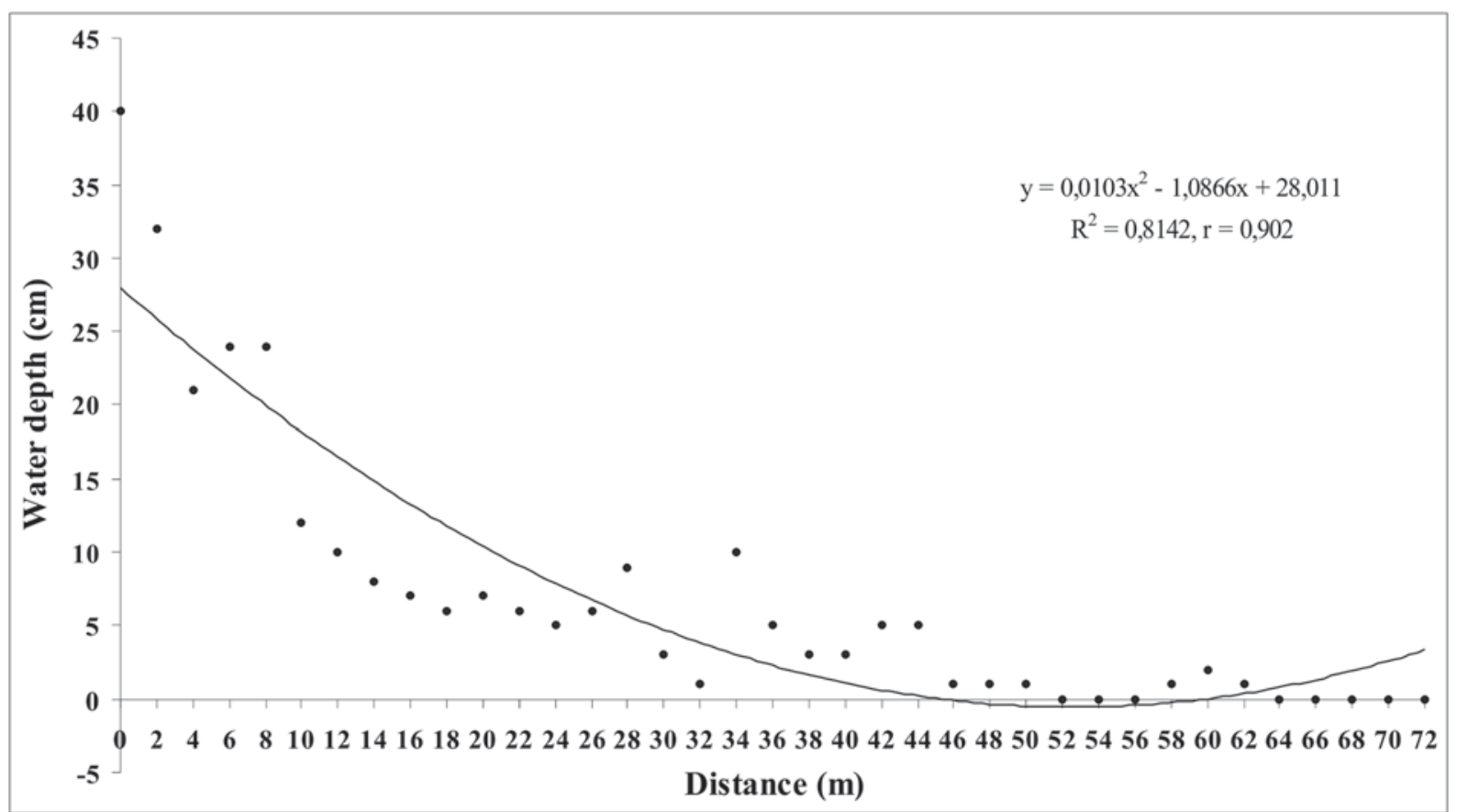

Fig. 5. The relation between distance and water depth. 


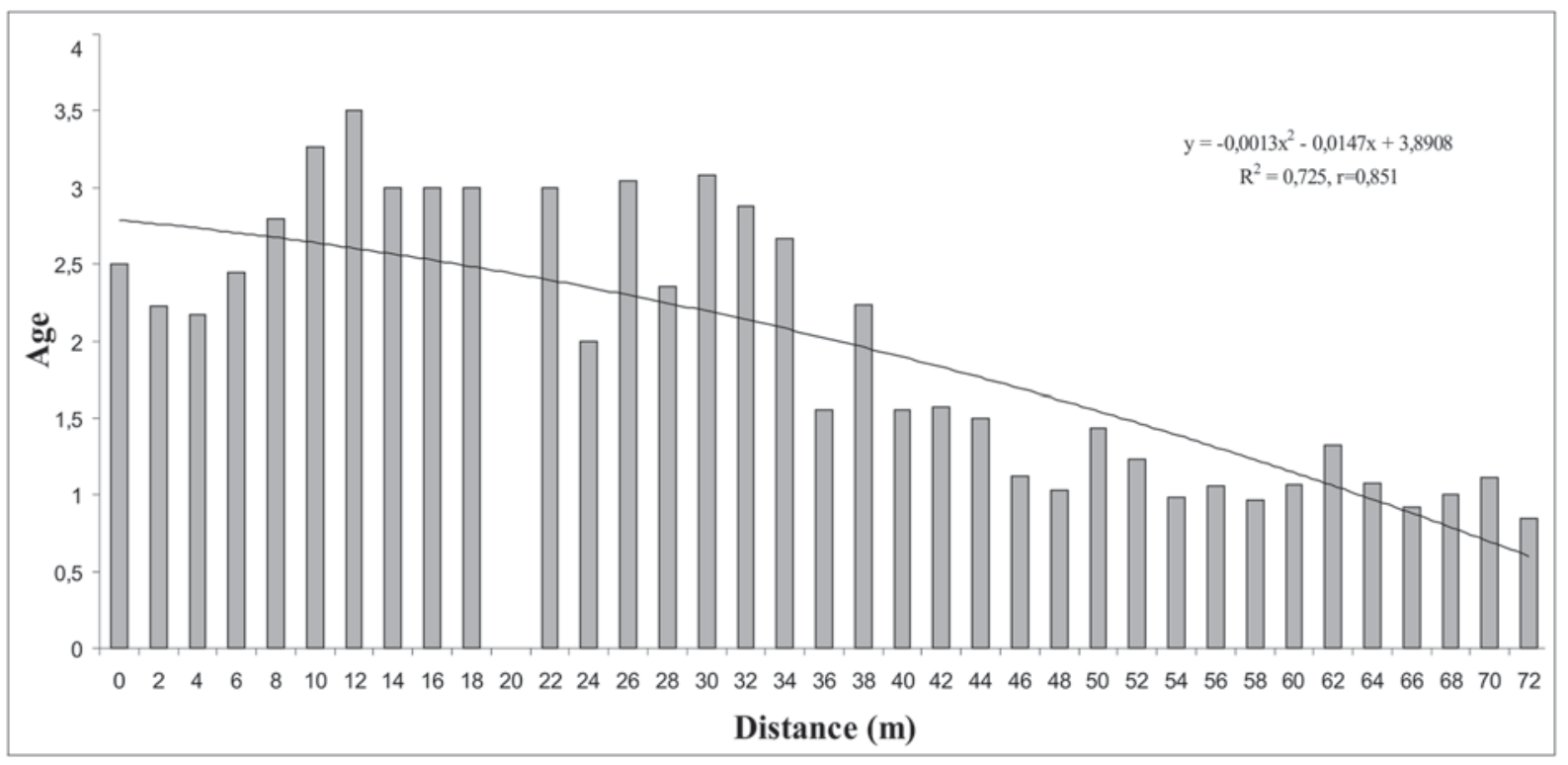

Fig. 6. Relation between distance and mean age.

Age analysis clearly shows that regeneration of woody vegetation began in the spring of 2011, the oldest willow stems harvested being four years old.

The transect was divided in two sectors based on observations related to the average growth so that we could sustain the hypothesis that in the plots $1-18$ regeneration of woody vegetation occurred in 2011-2012, and in the second group of plots between 2013-2014. This conclusion is supported by analysis of satellite images revealing that the second period coincides with the rise of water level by building the last beaver dam.

\section{Conclusion}

Beavers have a high modelling capacity on riparian habitats, more evident in wetlands with low slopes where they raise water level.

By raising water levels and deforestation beavers are initiating a new phase of ecological succession, the transition from forested wetland to shrub wetland, wet meadow, shallow marsh or deep water bodies. This is noticeable by changing the coverage of the different layers of vegetation. Simultaneously, composition and covering change dramatically in the same layer of vegetation. Deep and long-lasting flooding lead to poor development of alder trees, as evidenced by the quality and quantity of foliage or by reducing of annual growths.

The installing of woody vegetation has been gradual and followed the water level and slope gradient. The mean age per experimental plot decreases from 3.5 to 1 year as we move away from the origin of the transect (the waterfront). This allows us to sustain the hypothesis that the beavers create favourable conditions for installation of woody vegetation by raising the water level. The research will continue to determine which factors are determinants for reduced annual growing in the first years after germination.

On small areas satellite images can be useful to complete scientific data and explain event succession.

ACKNOWLEDGEMENTS. We thank all colleagues who contributed in any way to the development and improvement of this article. We express our gratitude to reviewers for constructive comments in sense of improving the manuscript.

\section{References}

Bonner J.L., Anderson J.T., Rentch J.S. \& Grafton W.N. 2009. Vegetative composition and community structure associated with beaver ponds in Canaan valley, West Virginia, USA // Wetland Ecology and Management. Vol.17. P.543-554.

Ionescu G., Ionescu O., Pasca C., Sirbu G., Jurj R., Popa M., Visan D., Scurtu M. \& Popescu I. 2010. Castorul in Romania: Monografie. Bucharest: Editura Silvica. [In Romanian]. Little M.A., Guntenspergen G.R. \& Allen F.H.T. 2012. Wetland vegetation dynamics in response to beaver (Castor canadensis) activity at multiple scales // EcoScience. Vol.19. No.3. P.246-257.

Rosell F., Borzer O., Collen P. \& Parker H. 2005. Ecological impact of beavers Castor fiber and Castor canadensis and their ability to modify ecosystems // Mammal Review. Vol.35. No.3-4. P.248-276.

Slabe J.T. 2007. Castor canadensis, the American beaver, a wetland ecosystem engineer // The Newsletter of the Colorado Riparian Association "Waters of the United States". Available online at http://www.beaversww.org/ beavers-and-wetlands/articles/wetland-engineer/ 